\title{
THE SOUTH AFRICAN HIGH SCHOOL HISTORY CURRICULUM AND THE POLITICS OF GENDERING DECOLONISATION AND DECOLONISING GENDER
}

\author{
DOI: http://dx.doi.org/10.17159/2223-0386/2016/n16a2 \\ Lindsay Wills \\ Centre for Women's Studies, University of York \\ lwills@wynghs.co.za
}

\section{Abstract}

In this article, I argue that the category of gender should be an essential consideration for a decolonised curriculum, and that gender theory should be included in its analytical toolbox for two reasons: firstly, because transformation of the curriculum has to foreground women's liberation by validating their experiences of, and contributions to, the past, and secondly, because gender has functioned as a key axis of power between men and women in the past. This study undertakes a critical analysis of the knowledge about women and gender forwarded by the current CAPS curriculum statement. Part of my objective is to reflect on what kinds of historical knowledge about women are considered "legitimate" by the curriculum, and to evaluate the ways in which this knowledge sustains or challenges an otherwise androcentric or masculinist history. In the main, however, I aim to show the ways in which the existing framework governing the South African history curriculum is unable to accommodate the kinds of knowledge and conceptual thinking required to give depth and meaning to women's experiences, and to examine how race and gender interact to produce and reproduce hierarchies and highly complex social relations. Feminist historians of empire and post-colonialism have long argued that race and class are gendered categories, and that gendered meanings therefore fundamentally shaped the imperial and colonial project. Gendering history in the South African curriculum would therefore entail revisiting many topics currently included in the curriculum and explicitly foregrounding the ways in which gender has functioned as a significant axis of power. This will not be a comfortable experience, especially given its implication in colonial violence, apartheid and the liberation struggle. Nonetheless, a number of FET topics deeply transformed by inclusion of this scholarship would open up new paradigms for negotiating the relationship between the past and the present.

Keywords: Gender; Women; History Curriculum; Transformation; Decolonisation; Curriculum and Assessment Policy Statement. 


\section{Introduction}

Feminist research has long established the fact that, in the main, women continue to be significantly underrepresented in high school history curricula and that these accounts of the past are more accurately described as "men's history". A central philosophical principle to this position is that a history which ignores the experiences of one-half of the world's population is, in fact, bad history (Adams, 1983). This field of research proposes that far from being the consequence of a heavy-handed conspiracy to deliberately exclude women, the continued underrepresentation of women is rather the product of a complex system of fallacies and unconscious bias. As Trecker (1971:260) argues, whilst this is a bias which broadly privileges an androcentric representation of the past, this is nonetheless a bias "so smooth, seamless and pervasive that it is hard to even begin to take a hold of it and bring it into clear view". It is for this reason that the inclusion of women into historical narratives needs to remain under close scrutiny.

Secondly, the theoretical challenges posed by women's and gender history to the discipline's very foundations involves, in no small way, getting to grip with the politics of the production of knowledge. History curricula are particularly potent sites for the construction and diffusion of knowledge and interpretations of how the past relates to the present. As such, national history curricula can be seen as extensions and vehicles of wider ideological and socio-cultural (im)balances of power and are thus often sites of political socialisation. Indeed, these were arguments forwarded by a large and diverse group of academics, curriculum advisors and educators pressing for a radically transformed history curriculum for a newly democratic South Africa in 1994 (see Siebörger, 1993). It is within a similar milieu of calls for transformation that I argue we need to see women's history as raising the ultimate challenge to decolonisation of the curriculum in two important ways. Firstly, like decolonisation, it demands that those previously marginalised be moved from the sidelines to the centre. Women's history has convincingly demonstrated the legitimacy of women's experiences as historical topics in and of themselves. Secondly, like decolonisation, it argues that radical re-imagining is required to account for multiple standpoints and perspectives, without which one hegemonic version of events is simply replaced by another. As argued by Joan Scott, women's history has shown itself to be more than an "innocuous supplement" (1993:241), but one which surfeits and therefore calls into question the traditional contours of what constitutes historical knowledge. 
I therefore suggest in the following discussion that short of a radical reorientation of themes and topics of history which can adequately account for the multiple identities and experiences women in the past have had, the current National Curriculum Statement (NCS) and Curriculum and Assessment Policy Statement (CAPS) will continue to privilege "masculinist" interpretations of the past which contributes not only to the general marginalisation of women as subjects of history but more importantly reinforces, or ignores, oppressive gendered ideas. In the current climate of transformation, where renewed attention is being paid to narratives long silenced and de-legitimised in South African higher education institutes, it is surely an imperative that the voices of women from the past are recovered and restored to the history taught to South African high school students. Decolonising gender in the history curriculum therefore means no longer accepting that accounts of the past which either gloss over or obscure women's experiences - especially Black women's experiences - are "true", "objective" and "universal". As Akhona Nkenkana urges, "The re-writing of African history that continues to disregard women is something that Africa's pursuit of its future should guard against" (Nkenkana, 2015:50).

A second and related argument for decolonising gender in the history curriculum seeks to problematise the ways in which gender is currently included in the curriculum. In this sense, I argue that it is not sufficient to simply add women into existing narratives. Indeed, a truly decolonised history curriculum is concerned with examining the gendered systems which historically gave rise to women's varying experiences of oppression in the first place. As Nkenkana also writes, "Decolonial history, as far as gender is concerned, must move beyond the use of males as the subject of humanity against which women are measured. Gender must be looked at as a system and as structures which deprived both men and women of humanity" (Nkenkana, 2015:53).

The following discussion is organised around a critique of a selection of CAPS FET history topics and units. These are organised around three key themes: the question of women's differing experiences, the concept of intersectionality, and nationalism, race and gender. As they show, there is enough evidence of the inclusion of women's experiences, and scholarship in women's history, to suggest that the current CAPS document is not an entirely male-dominated curriculum. Nonetheless, as it stands, if we are to pursue decolonisation of the curriculum at all, "mentioning" women is not a radical enough move towards 
conceptualising women and representing gendered historical concepts in ways which do not re-inscribe a practice of epistemic erasure or the textual inscription of damaging stereotypes and ideologies.

\section{Decolonising claims about women's political consciousness}

I am interested in analysing the extent to which the curriculum provides room to engage with what Offen suggests is "the difference difference makes" when representing women's particular "consciousness of their own distinct role in society" (1988:226). This requires engaging with the idea that gender is an axis cross-cut by race, class and sexuality, and that "woman" is not a universal sign but the embodiment of inter-locking and shifting categories of identity. I would like to propose here that whilst CAPS goes some way towards including women in this way, it is nonetheless a contested accommodation, and that likewise, the representation of women especially within these topics has acute consequences for the extent to which hegemonic gender ideologies are sustained.

It seems that the notion that differences shape not only women's experiences, but their relations with one another, is unevenly - perhaps even precariously - broached by the CAPS document. This is most obvious in the outline of content relating to the role of women in civil society protests of the 1960s and 1970s, where the reference to "difference" is in effect little more than a token gesture and works to re-inscribe the hierarchies of power it attempts to destabilise. As I approach it in my discussion, this is to ask of each claim about women's experiences, "does this apply as equally to some women as it does to others?"

I start first with an analysis of the claims made by the curriculum to "know" different women's consciousness of their differing socio-political locations to one another, or of claims about what constituted women's historical "identities" and how women historically "saw themselves". The following is therefore an analysis of the discourse nestled within the Grade 12 unit, "Women's liberation and feminist movements in the 1960s and 1970s: a middle class movement in industrialised countries" (DBE, 2011:28). I argue here that the problem is not just that the curriculum's language pivots on a particular definition of feminism, but also that even as the unit title seems to want to reject ethnocentrism, the two remain ideologically wed, resulting in a textual legitimisation of the very discourse it claims to critique. I argue 
that this amounts to something of a textual erasure of black or so-called Third World women, who end up, in the Spivakian sense, unable to speak (1988:76) and are instead spoken for in terms set by a reactionary, masculinist definition of anti-racism and anti-imperialism.

It has become axiomatic that aspects of the second wave feminist movement were at times antithetical, even hostile, to other women's struggles which did not regard the dismantling of so-called patriarchy as their primary goal; the deep cleavages between feminism and anti-racism, for example, have been documented by a large body of scholarship (see Davis, 1981; hooks, ${ }^{1}$ 1981; Spelman, 1989; Hill Collins, 1990). Therefore taken at its strongest arguments, the curriculum reflects a partially accurate history of second wave feminism. Here, feminism is arguably being given here to students in the vocabulary of "rights", a version of feminism largely defined by its ideological ties to the values of liberal equality and freedom of the individual (a notion not technically wrong nor anachronistic to the historical period under examination). Nonetheless, what the curriculum and textbooks would also require remain central to this unit is presumably the critique the women's liberation movement was classist and Eurocentric. Again, given the definition of feminism implied by this unit of the curriculum, this internal logic makes sense. However, shoring up - indeed, implying that - the essence of feminism is primarily concerned with a liberal and rights-based ideology is what enables this discourse to sidestep other feminisms which have historically taken exposure of the constructed, and therefore social, nature of gender roles as their political objective. Furthermore, testing the internal logic of the unit reveals how its message seems to be haphazardly applied. In the following I argue that suggesting a woman's experience of racism was somehow more pressing and distinct from her experience of sexism pursues a false binary which works to erase the subjectivity of Black women.

In the first instance, if, as implied by the curriculum, the struggle for race equality was indeed more important to black women than gaining gender equality, the obvious question to be asked is why black women do not therefore feature more predominantly in the sections devoted to these topics, or, at the very least, are consistently mainstreamed into topics like the Civil Rights Movement and Black Power. Secondly, it is historically misleading to suggest that second-wave feminism was a movement isolated in the manner framed by the curriculum. For example, in 1977, the Combahee River Collective Statement laid out the genesis and theory of a black feminism,

1 At request of the author the surname of Hooks is referenced in lower case. 
stating that "...we are actively committed to struggling against racial, sexual, heterosexual, and class oppression and see as our particular task the development of integrated analysis and practice based upon the fact that the major systems of oppression are interlocking", and that black feminism sought to "develop a politics that was anti-racist, unlike those of white women, and antisexist, unlike those of Black and white men" (Eisenstein, 1978:210-211). Indeed, bell hooks suggests that it is in fact symptomatic of a racist narrative of the women's movements to assume that the absence of black women from women's liberation movements is a sign of their disinterest in feminist struggles (1981: 161). The ultimate irony is therefore that it was in fact black women identifying as feminists who exposed the racism of second wave feminism, and who have emphasised the inseparability of race, gender and class from a woman's thoughts and experience (Hill Collins, 1990; Crenshaw, 1991; Higginbotham, 1992). There is a clear political injustice to this claim, not the least of which, as Amos \& Parmar suggest, is that it ends up "appropriating feminism for white women" (1984:8).

Finally, the categorical errors I have outlined above have particular consequences for how women's consciousness of their role in South African society, and their contributions to anti-apartheid struggles, are described in the curriculum statement. Given that the myth of sisterhood in the South African struggle against apartheid has been squarely laid to rest (see Hassim, 1991; Fouche, 1994), it is not wrong to suggest that in a nation so deeply stratified by race, black and white women rarely shared the same struggles. What is problematic however are the claims made about women's identity politics: that "black women see themselves first as black, and white women see themselves first as white" (DBE, 2011:28). I have outlined above how contentious it is to suggest that women are able, and somehow willing, to extract one aspect of their identity from another, but it is still worth exploring some of the subtext of this textual posture as it relates to representations of whiteness, blackness and gendered consciousness in the politically fraught South African context. Not only are claims like the above a drastic simplification of the complexities of women's consciousness - almost to the extent of epistemic violence (Spivak, 1988) - but it also works to conceptually let white women off the proverbial hook because, by the curriculum's own logic, the idea of foregoing "gender" when issues of "race" were more pressing in practice only actually applied to black women. Furthermore, as Elsa Brown (1992:298) argues, asymmetrical relationships of power between women are not abstract, but relational and contingent. Brown argues, it is not enough to mention 
differences between women, what has to be explicated instead is the fact that "[w] hite women and women of color not only live different lives but white women live the lives they do in large part because women of color live the ones they do". The lost opportunity here, therefore, is to explicate how white and black South African women have historically interacted, and to offer the opportunity to explore how gendered historical contexts have shaped black and white women's identities as gendered and racial precisely because they are relational. Finally, such a claim goes some way towards encouraging what Maria Lugones terms "epistemological blinding" (2008:1) when categories like race and gender are separated from one another. The specificity of black South African women's experiences of racism, disempowerment and sexual violence becomes distorted and displaced when gender and race are not presented as intermeshing points of self-identity.

Nonetheless, there is still some tricky conceptual work to be done here with the questions of gender identity, feminist politics and the South African liberation struggle the authors of the NCS have clearly grappled with. As Anthias \& Yuval-Davis (1983) write “... once we stop perceiving western white feminism as providing the ultimate criteria for defining the contents of feminism, we are faced with the problem of how to politically evaluate various women's struggles". I think that what is at the heart of my critique is a sense that what is at stake in this unit of South African women's history are not only speculations about the nature, and substance of women's contributions to the liberation struggle, but also the idea of women's rights, or women's issues, having an inherent value and relevance. These are no less politically charged questions in the present than they were during the liberation struggle itself (see for example, Hassim, 2009). I thus venture to suggest that in the absence of a more extensive analysis of the inter-workings of gender roles and nationalism a great intellectual price is paid at the expense of the powerful complexities of women's participation in nationalist struggles. As such, perhaps the curriculum ought to advance the idea that gender played a role in the demise of apartheid, and the subsequent process of decolonisation in South Africa, and, at least to my mind, what this requires is injecting gender into the larger tapestry of the curriculum as a whole. 


\section{Towards a gender-oriented history curriculum}

The fact that women have demographically constituted half of humankind ${ }^{2}$ poses an inescapable conceptual challenge to the notion of a "general history"; thus, as Gisela Bock (2006:106) writes, "it is no less problematic to separate the history of women from history in general than to separate the history of men - and even more so, truly general history - from the history of women. Women's history concerns not merely half of humankind, but all of it". Given this argument, it is therefore impossible to continue to represent the past in ways which bear no relevance to the experiences of women - as Laura Downes (2004: 4) points out, "to write a history without women was a foolhardy endeavour indeed, for it would be to tell barely half the story".

Gender theory, first finding its footing in the 1970s (see: Oakley, 1972; Rubin, 1975) came to be used by feminist historians as a means to describe how gender, defined as knowledge of sexual difference, has functioned as a dynamic force of social organisation: what is categorised and recognised as "female" is always in an orbital yet asymmetrical relation to what is categorised and recognised as "male", and acts to shape the meanings given to human behaviour. Gender theory thus brought to historiography a way to examine relations between men and women as the constitutive element of all historical social relations. Firstly, gender history ensures that for the first time, men as sexed bodies and socialised as masculine become visible in historical narratives; when men and masculinity become "categories" of analysis, it is no longer only women who appear to have a "gender", and whose presence in history has been premised on their sex/gender, largely determined by having a sexed body capable of reproduction. Secondly, "a truly general and unbiased account of the past has to abandon the pretext that the masculine represents a neutral and universal representation of the species" (Downs, 2004:4) and either draw constant and critical attention to the "the gendered constitution of their object of analysis" (Downs, 2004:4), or, as Helen Bradford points out, "remain flawed by the inapplicability of interpretations to the female majority" (1996:352). Finally, the extensive work of black, Chicana, Asian and queer feminist theorists has shown that knowledge of sexual difference is always-already knowledge of other differences. It is thus that gender offers both a good way of thinking about history, about the ways in which hierarchies of differences - inclusions and exclusions - have been constituted, and of

2 I am aware of the claims I am myself making about gender; the claim as I make it here rests on the a priori claim about what constitutes the category "woman", and therefore what constitutes the category of "man". As this is an immense theoretical field on its own, I can only apologise to (especially) Butler (1990) and Scott (1988). 
theorising (feminist) politics (Scott, 1999:10). It is from this perspective that one might begin to evaluate to what extent gender is recognised by the curriculum as a crucial determinant of historical events. At the same time, discerning the ways in which the syllabus stresses gender in its selection of topic matter is also to begin questioning to what extent the syllabus itself "becomes part of the politics of the gender system" (Scott, 1988:15).

In the following discussion, I seek to argue that race and nationalism are the "big questions" (Bradford, 1996:355) which govern the South African history syllabus as a whole. This is a position which I borrow from Peter Callaway's (2012) suggestion that the curriculum is dominated by discourses of race and nationalism, which he argues, comes at the expensive of some historical complexity and context. I seek to suggest that the picture that begins to emerge from the syllabus is one where nationalism's gendered hierarchies are subsumed under discussions where a conceptual premium is placed on the discourse of democracy and civil rights, and, accordingly, the instrumental role played by race, all of which are, ironically, historical concepts themselves shaped by gender. I therefore propose that the deepest and most elusive layers of gender ideology embedded in the curriculum's subtext can be surfaced through a macro- and micro-analysis of narratives of colonialism, institutionalised racism and struggles of nationhood and/or democracy.

Stoler (1995:342) argues, for example, that if colonial control was predicated on distinguishing between racial differences, it has to follow that colonial control therefore rested on notions of gender. Control of sexual arrangements was paramount for the establishment of colonial categories of racial difference. Colonial authority depended on discerning and attributing femininity, masculinity and sexuality to racially marked bodies. Thus, where the concept of gender is inseparable from the concept of race, Scully (1995:342) argues that "sex in the colonies was a political act with repercussions", emanating especially from the categorical imperative of designating offspring as either "coloniser" or "colonised". However this is a significantly minimalised aspect of the colonial project as it is outlined by the CAPS document, especially absent, for example, in the Grade 10 topic, "European expansion and conquest during the 15th and 18th centuries" (Topic 2; DBE, 2011:14), which outlines teaching of how the Spanish, Portuguese, Dutch and British came to dominate trade and colonise large parts of the globe. The emphasis is instead on "the processes of colonisation", the "consequences on the colonised societies", and "ideas of racial superiority" (Topic 2; DBE, 2011:14), 
Similarly, Tessie Lieu writes that, "we tend to think that race is a relevant social category only when we encounter racism as a social phenomenon, in the form of bigotry, for example.... As a result, scholars have let the ideologies of racism [Liu describes this as an obsession with skin colour, skull size and intelligence] set the agenda for discussion of racism within the academy" (1991:269). This, I would argue, is a helpful way of understanding the approach the syllabus generally takes towards structuring the historical theme of institutionalised racism. I also find myself relying here on Gisela Bock's argument that "...the language of racism is obsessed with the sexes and sexuality, and it contains a characteristic mixture of sexuality, blood and violence.... Racism cannot be understood without understanding its gender dimensions, which is one of its constituent factors". (2006:115).

By way of example, for instance, within the Grade 11 section, "Ideas of race in the late 19th and 20th centuries" (DBE, 2011:21), some of the crucial details of gender and sexuality seem to have become submerged under heavy emphasis on race, vis-à-vis Social Darwinism and eugenics. Thus, whilst some of the technologies of eugenics - "family planning," "selective breeding" etc. - are broached, the fact that these were profoundly gendered processes is subsumed under a heavy emphasis on the discourses of racism, i.e. hierarchies of racial superiority and inferiority, a fact firmly underscored by the use of the genocides as case studies (the Nama and Herero people in Namibia, the Aboriginal people of Australia and Tanzania, and the Holocaust).

Finally, given the literal codification not only of the illegality, but immorality, of sexual contact between races under the apartheid regime, the potent role played by ideas of race and sexuality to the construction of Afrikaner nationalism should form a crucial component of the topic on the whole. Rather, the topics included in the syllabus under the topic of the rise of Afrikaner Nationalism (Grade 11, Topics 4 and 5; DBE, 2011:22) show that this is intended to be content focused around describing economic affirmative action, the contestation over the franchise for black South African men, and job reservation. Ironically, of this, this actually does mean that the Grade 11 curriculum preserves precisely something McClintock describes as Afrikaner nationalism's fundamentally gendered origins, that is, "white male interests, white male aspirations and white male politics" (1993:68) and corresponds to Cynthia Enloe's argument that "nationalism has typically sprung from masculinized memory, masculinized humiliation and masculinized hope" (1990:45). In the meantime, what has nonetheless been rendered invisible 
are the politics of obsessive patriarchal control of white female sexuality (see Klausen, 2010) before and during apartheid, and the nature of Afrikaner women's multi-fold contributions of domestic and ideological labour to the growth of Afrikaner nationalism by the mid-20th century.

It is precisely in these purportedly "gender-neutral" historical units that a feminist interpretation of the curriculum's claims to represent the universal condition involves asking the question, "did/ does this apply as equally to women as it did/does to men"? At stake is to what extent the syllabus has included topics which draw attention to the gendered dimensions of the political projects of nationalism and democratic citizenship. My deconstructive approach here is firstly informed by the work of feminist political scientists, who, like Carole Pateman (1989:210) have pointed out that, "[f]or feminists, democracy has never existed; women have never been and still are not admitted as full and equal members and citizens in any country known as a 'democracy", and who have written of their suspicion of liberal democracy's claims about gender. It is also indebted to the insights of feminist scholars of nationalism, interested in the nuances and complexities inherent to women's participation in mass liberation movements, especially in the so-called "Third World" (see Mohanty, et. al., 1991; Anthias \& Yuval-Davis, 1983).

A liberal historiography, as is the one woven through the South African curriculum, considers a nation's struggle for self-determination "evidence of progressive realisation of an individualistic and cultural order and maintains that women eventually benefited from these advantages" (Kelly, 1984:3). This is a useful approach to unpacking the curriculum's overarching emphasis on nationalism. Firstly, in this narrative, attainment of full democratic citizenship and its accoutrement of universal equality before the law, is treated as the sine qua non of an individual's freedom. Secondly, even if the curriculum seeks to encourage a reflection on the inherently constructed and exclusionary practice of nationalism and nationhood, as evinced by the "key question" for the Grade 11 unit, "When is nationalism beneficial and when is it destructive?" (DBE, 2011:22), this only goes so far as to posit it as a reductive binary of "good" and "bad" nationalism. A feminist critique of nationalism argues that this misses a crucial point: that is, that the conversation about nationalism should be one that starts by turning a critical eye to its fundamentally gendered practice.

Perhaps, in the first instance, this is of course because the foundations of the "modern democracy" which lie in the French Revolution, were in fact founded on ideas antithetical to the concept of gender equality, as is evinced by the 
"fraternity" and "brotherhood" of the "Liberté, égalité, fraternite" phrase. However, this is not demarcated as an area of concern in the outline for the French Revolution in Grade 10, even though the key question here is "how did the French Revolution lay the foundations for modern democracies?" (DBE, 2011:15). This does not problematise the notion that, historically, women qua women were not considered to have inherent rights, and only goes so far as to explain that granting of such rights to women have happened as a product of changing historical contexts. Furthermore, this also does not problematise the idea that it is from "male" citizenship that "women's citizenship" is to be derived and measured either. Feminist citizenship theory has long argued that liberal citizenship conflates having rights with the ability to exercise rights. A student will be hard pressed to find an engagement with why it is because of hegemonic gender regimes that women continue to remain secondary citizens, even when rights have been "achieved". An overt conceptual preoccupation with the supposedly gender-blind concepts of political rights and public rights means that this is the extent to which "equality" is broached, rather than, as gender activists would argue, the ways in which citizenship has always been governed by sexual politics.

Feminist scholarship on nationalism has argued that the relationship between women and nationalism is one which resists simple explanations. It is often nationalism which, as Cynthia Enloe writes, "has provided millions of women with a space to be international actors... [which has] induced many women to feel confident enough to take part in public organising and public debate" (1990:61), even if its main values and organisations resist substantial changes in women's gender roles. It is therefore because the issue of South African women's participation in the anti-apartheid struggle pulls to itself a radioactive combination of notions of race, gender and the processes of nationalism that I argue this is delicate, complex terrain, and any syllabus outlines which sought to do it justice would need to be very finely tuned.

I want to return to my earlier analysis of content included under the Grade 12 unit, "Civil Society Protests" and the claim that "black women see themselves first as black, white women see themselves first as white" (DBE, 2011:28). This quite clearly advances the idea that women's issues as a priority of its own were at times considered irrelevant by black South African women, and by implication white and Western, and thus complicit with the very system the anti-racist liberation struggle fought to throw off. What is not made clear, however, is what Anthias \& Yuval-Davis suggested with their question, "how 
do we evaluate women's political struggles?" I would argue that this is where the history of women's participation in key moments of national history is at its most vulnerable. Thus, even though CAPS specifies the ways in which both black and white women used activities traditionally specified as "women's activities", such as trade union organisations, peaceful anti-pass campaigns, beer-brewing and boycotting municipal beer halls (DBE, 2011:28) as ways to resist apartheid, what gets lost in a narrative are two distinct, but inter-related aspects. The first is the fact that contested gender roles within the liberation movement itself were the key mechanisms shaping this paradigm as a whole. Secondly, suggesting that a black women's experience was first mediated by her black skin and not a consciousness of the specificity of her experience of women's issues within the movement, actually ends up sustaining two harmful narratives: it ensures the discursive stabilisation of the idea that black men's struggles were unrelated to their gender and sexuality, which moves the curriculum towards somewhat verging on complicity with what Enloe (1990:62) calls the "not now, later" narrative, or the idea "that the most dire problems facing the nascent national community are problems which can be explained and solved without reference to power relations between women and men". As such, what is left unexamined are the ways in which women's issues - as they are now, and were then - have historically faced constant struggles to resist segregation and marginalisation.

Finally, I would venture to argue that it is not only a false dilemma that women in South Africa were having to deliberately choose between "feminist and/or women's issues" or "mainstream anti-racism" approaches in their struggle against the apartheid state, but that it is the choice of topics about women's participation which gives rise to this. By doing so, I am borrowing from Nomboniso Gaza's retort, "why the Berlin Wall between blackness and liberation on one hand and feminism on the other?" (2007:214), and the essence of her wider argument, that binary thinking - trying to find distinctions between the two or attempt reconciliation of them in the South African context - is unnecessary and does not make sense of black women's experience of the struggle. In practice this is to argue that, as they stand, the approach to topics which do include women's involvement in the liberation struggle corresponds to an androcentric perspective of historical events. It is an unfortunate fact that women's varied and multiple contributions to the anti-apartheid struggle do not feature with the same predominance as South African men's do. The 1956 Women's March appears in both Grades 11 and 12 content, for example, but despite a chapter dedicated to the rise of 
African nationalism in Grade 11, the dynamic history of the African National Congress Women's League is absent from topics relating to the diverging political stances of the ANC, ANCYL and PAC between 1912 and the late 1960s. And yet, historians of women in South African history have long been interested in the role played by the discourse of "motherisms" (see for example, Meintjies, 1998ab; Kemp, 1995; Hassim, 2006) among black South African women in the liberation struggle. Whilst masculinist language often seeped through African National Congress nationalism, Meintjies writes, "women did not eschew the symbolism embedded in the idea of 'mothers of the nation', they used it to establish for themselves a secure public role" (1998a:104). This research underscores the notion that it is an imposed narrative that women in South Africa in general saw inconsistencies between the demands made of their gender, and demands made on them by the liberation struggle.

Themes like race and nationalism are as complex as they are radioactive. I would argue that it would be of absolute necessity that they appear in any history curriculum. Nonetheless, as I have shown in this discussion, it is an incomplete picture which emerges when the concepts of either race or nationalism are dealt with in a way which elides gender as a substantive element of their mechanisms. As I have also argued, it is even more so the case when race and nationalism are not considered bound by the politics of gender in history. Elizabeth Spelman agrees that this is a demanding exercise, pointing out that "it is not easy to think about gender, race and class in ways that don't obscure or underplay their effects on one another" (1989:115). As she continues, however, "the crucial question is how the links between them are conceived". In order for students to conceptualise these "big questions" of history in such a way that it is not flawed by androcentric diagnoses - and which therefore do not take into account the reciprocity of gender roles - this approach to history will by necessity need to discuss themes of sexualised violence, racially gendered violence, gendered citizenship and the idea of multiple feminisms and gender consciousness.

Whilst it is clear that the South African curriculum has, to some extent, responded to the demands that history taught to high school students must reflect women's historical experiences and identities, I have sought to argue that this does not yet amount to a real move towards a gender-balanced, nor gender-sensitive representation of the past. Indeed, I have argued that the very act of representing women in history textbooks strains the limits of existing frameworks. Either there must take place a radical reconceptualization of 
topics and language deployed in representing the past, or "including" women in history will remain a practice not just conceptually inadequate, but susceptible, or worse, bound, to representations of women which re-inscribe harmful stereotypes and reproduce oppressive notions of gender. As I have shown, it is rare to come across a site of so-called "middle-ground".

Finally, the imperative of decolonisation gives this discussion a particular urgency. When women remain under-represented, and their experiences distorted through a largely androcentric account of the past, it is a naïve claim that the content of the South African FET history curriculum can help students answer its key question, "How do we understand our world today?" (DBE, 2011:10). Who, in the first instance, is included by such a term as "we"? Which "world" is it that ought to be understood? On the basis of which version of the "past"? My proposal has been that a school history that takes the experiences of women into serious consideration will look significantly different to how it appears now, and it will only be at this point that school history as it is taught in South Africa will enable students to imagine a multiperspectival past.

\section{References}

Adams, C 1983. 'Off the Record', Teaching History, 36:3-6.

Amos, V \& Parmar, P 1984. Challenging imperial feminism, Feminist Review, 17:3-19.

Anthias, F \& Yuval-Davis, N 1983. Contextualizing feminism: Gender, ethnic and class divisions, Feminist Review, 15:62-75.

Bourdillon, H 1994. On the record: The importance of gender in teaching history. In: H Bourdillon (ed.). Teaching History: a Reader, London, New York: Routledge.

Bock, G 2006. Women's history and gender history: Aspects of an international debate. In: S Morgan (ed.). The Feminist History Reader, London: Routledge.

Bradford, H 1996. Women, gender and colonialism: Rethinking the history of the British Cape colony and its frontier zones, c. 1806-70. The Journal of African History, 37(3): 351-370.

Brown, EB 1992. "What has happened here?": The politics of difference in women's history and feminist politics. Feminist Studies, 18(2):295-312. 
Butler, J 1990. Gender Trouble: Feminism and the subversion of identity, New York: Routledge.

Callaway, P 2012. History in senior secondary school CAPS 2012 and beyond: A comment. Yesterday \& Today, 7:23-63.

Combahee River Collective 1978. A Black Feminist Statement - dated April 1977. In: Z Eisenstein (ed.). Capitalist patriarchy and the case for socialist feminism, New York: Monthly Review Press.

Crenshaw, K 1991. Mapping the Margins: Intersectionality, identity politics, and violence against women of color. Stanford Law Review, 43(6):1241-1299.

Davis, A 1981. Women, Race \& Class, London: Women's Press.

Department of Basic Education (DBE) 2011. National Curriculum Statement (NCS): Curriculum and Policy Statement (CAPS), History, FET Grades 10-12. Pretoria: Government Printing Works.

Downs, L 2004. Writing gender history. London: Hodder Education.

Enloe, C 1990. Bananas, beaches \& bases: Making feminist sense of international politics, $1^{\text {st }}$ edition. Berkeley: University of California Press.

Fouche, F 1994. Overcoming the sisterhood myth. Transformation, 23:78-97.

Gasa, N 2007. Women in South African history: They remove boulders and cross rivers ('basus"imbokodo, bawel'imilambo). Cape Town: HSRC Press.

Hassim, S 1991. Gender, social location and feminist politics in South Africa. Transformation, $15: 65-84$.

Hassim, S 2006. Democracy's shadows: Sexual rights and gender politics in the rape trial of Jacob Zuma. African Studies, 68(1):57-77.

Higginbotham, EV 1992. African-American women's history and the metalanguage of race. Signs, 17(2): 51-274.

Hill Collins, P 1990. Black feminist thought: Knowledge, consciousness, and the politics of empowerment. Boston: Unwin Hyman Press.

hooks ${ }^{3}$, b 1981. Ain't I a Woman? Black women and feminism, Boston: Southend Press.

Kelly, J 1984. Women, history, and theory. Chicago: University of Chicago Press.

3 At request of the author, the surname of Hooks is referenced in lower case. 
Kemp, A, Madlala, N, Moodey, A \& Salo, E 1995. The dawn of a new day: Redefining South African feminism. In: A Basu. The challenge of local feminisms: Women's movements in a global perspective. Colorado: Westview Press.

Klausen, S 2010. Reclaiming the white daughter's purity: Afrikaner nationalism, racialised sexuality, and the 1975 abortion and sterilisation act in apartheid South Africa. Journal of Women's History, 22(3):39-63.

Lieu, T 1991. Teaching the differences amongst women from a historical perspective: Rethinking race and gender as social categories. Women's Studies International Forum, 14(4):265-276.

Lugones, M 2008. The coloniality of gender. Worlds and Knowledge Otherwise, Spring: 4-17.

McClintock, A 1993. Family feuds: Gender, nationalism and the family. Feminist Review, 44:61-80.

Meintjies, S 1998a. Political violence and gender: A neglected relation in South Africa's struggle for democracy. Politikon, 25(2):95-109.

Meintjies, S 1998b. Winnie Madikizela Mandela: Tragic figure? Populist tribune? Township tough? South African Report, 13(4):14-22.

Mohanty, C, Russo, A \& Torres, L 1991. Third world women and the politics of feminism. Indianapolis: Indiana University Press.

Nkenkana, A 2015. No African futures without the liberation of women: A decolonial feminist perspective. Africa Development, 40(3):41-57.

Oakley, A 1972. Sex, gender and society. London: Maurice Templeton Smith.

Offen, K 1988. Defining feminism: A Comparative historical approach. Signs, 14(1):119-157.

Pateman, C 1989. The disorder of women: Democracy, feminism and political theory, Cambridge: Polity Press.

Rubin, G 1975. The traffic in women: Notes on the political economy of sex. In: R Reiter (ed.). Towards and anthropology of women. New York: Monthly Review Press.

Scott, JS 1988. The problem of invisibility. In: S Kleinberg (ed.). Retrieving women's history: changing perceptions of the role of women in politics and society. Berg: UNESCO.

Scott, JS 1993. Women's History. In: L Kaufman. American feminist thought at century's end: A reader. Cambridge: Blackwell. 
Scott, JS 1999. Gender and the politics of history. Revised edition. New York: Columbia University Press.

Spelman, E 1989. Inessential women: problems of exclusion in feminist thought. London: Women's Press.

Siebörger, R 1993. History and the emerging nation: The South African experience. International Journal of Historical Learning, Teaching and Research, 3(2):1-17.

Spivak, GC 1988. Can the subaltern speak? In: C Nelson \& L Grossber (eds.). Marxism and the interpretation of culture. MacMillan: Basingstoke.

Stoler, AL 2002. Carnal knowledge and imperial rule: Race and the intimate in colonial rule. Berkeley: University of California Press.

Trecker, L 1971. Women in United States History high school textbooks. Social Education, 35:429-260, as quoted in $A A U W$ report, No. 62. 